\title{
STUDI KASUS: UPAYA PENURUNAN NYERI PADA KLIEN POST HEMOROIDEKTOMI DI RSK NGESTI WALUYO PARAKAN TEMANGGUNG
}

\author{
Agustinus Kri Ediyanto* \\ *) Rumah Sakit Kristen Ngesti Waluyo Parakan Temanggung, Jl. Pahlawan, Jubug, \\ Wanutengah, Parakan, Kabupaten Temanggung, Jawa Tengah 56254, email: \\ akriedi1010@gmail.com
}

Corresponding Author: Agustinus Kri Ediyanto

\begin{abstract}
Abstrak
Hemoroid atau yang sering dikenal dengan penyakit wasir atau ambeien merupakan penyakit yang sangat umum terjadi di masyarakat dan sudah ada sejak jaman dahulu. Saat ini tindakan penyembuhan hemoroid yang menjadi gold standart adalah operasi hemoroidektomi. Namun nyeri post operasi hemoroidektomi masih menjadi masalah besar yang disebabkan oleh spasme perianal. Tujuan dari penulis dapat memahami asuhan keperawatan pada pasien dengan nyeri post hemoroidektomi dengan melaporkan tindakan nonfarmakologi terhadap penurunan nyeri. Metode yang digunakan penulis adalah metode deskriptif dengan pemaparan studi kasus melalui pendekatan asuhan keperawatan yakni pengkajian, penegakan diagnosa keperawatan, perencanaan, implementasi, dan evaluasi keperawatan. Tindakan keperawatan $3 \times 24$ jam yang dilakukan pada klien dengan post hemoroidektomi adalah mengajarkan teknik non- farmakologi untuk menurunkan nyeri yaitu menganjurkan klien untuk memilih posisi yang nyaman dan memberikan bantalan flotasi saat duduk, mengajarkan klien relaksasi nafas dalam, dan mengajarkan klien teknik distraksi. Masalah nyeri akut teratasi sebagian sehingga membutuhkan perawatan lebih lanjut dan kerjasama dengan tim medis lain, klien dan keluarga sangat diperlukan untuk keberhasilan asuhan keperawatan.
\end{abstract}

Kata kunci: Hemoroidektomi, Nyeri, Teknik Non Farmakologi

\section{PENDAHULUAN}

Hemoroid atau yang sering dikenal dengan penyakit wasir atau ambeien merupakan penyakit yang sangat umum terjadi di masyarakat dan sudah ada sejak jaman dahulu. Kejadian hemoroid cenderung meningkat seiring bertambahnya usia seseorang, dimana insidennya lebih tinggi pada seseorang yang berusia 20-50 tahun. Pada usia diatas 50 tahun ditemukan 50\% populasi mengalami hemoroid (Black \& Jane, 2014). Data prevalensi hemoroid dalam skala internasional maupun nasional saat ini belum pasti karena hemoroid bukanlah penyakit yang mengancam jiwa. Tetapi terdapat sebuah penelitian tentang prevalensi hemoroid pada orang dewasa dengan hasil dari 976 responden didapatkan 380 responden $(38,93 \%)$ mengalami hemoroid. Pada 277 responden (72,89\%) hemoroid diklasifikasikan sebagai grade I, 70 responden Ediyanto, A.K. / Studi Kasus: Upaya Penurunan Nyeri Pada Klien Post Hemoroidektomi... Hal 32 dari 57 
Jurnal IImu Keperawatan Medial Bedah 1 (2), Desember 2018, 1-57

ISSN 2338-2058 (print), ISSN 2621-2986 (online)

$(18,42 \%)$ sebagai grade II, 31 responden $(8,16 \%)$ sebagai grade III, dan 2 responden $(0,53 \%)$ sebagai grade IV. Kemudian 170 responden $(44,74 \%)$ mengeluhkan gejala yang berhubungan dengan hemoroid sedangkan 210 responden $(55,26 \%)$ melaporkan tidak ada gejala (Riss et al., 2012).

Di Indonesia sendiri untuk penelitian prevalensi dalam skala nasional juga belum diketahui pasti. Hal ini dikarenakan penderita hemoroid cenderung malu untuk mengutarakan penyakitnya, selain itu hemoroid bukanlah penyakit yang mengancam jiwa. Menurut penelitian, tipe hemoroid yang paling banyak ditemukan adalah hemoroid eksterna 49,49\% diikuti hemoroid interna 26,80\% kemudian hemoroid campuran 23,71\%(Septadina \&Veronica, 2015).

Faktor resiko terhadap kejadian hemoroid adalah aktifitas fisik sering mengejan bila BAB merupakan faktor risiko paling tinggi kejadian hemoroid (Sunarto, 2016) dan merupakan pencetus terjadinya hemoroid (Rani, Simadibrata, Syam, 2011). Akibat jika hemoroid yang tidak segera ditangani akan menimbulkan komplikasi yaitu perdarahan yang dapat menyebabkan anemia defisiensi besi, trombosis yang dapat membuat nyeri yang intens, dan 3 strangulasi hemoroid merupakan prolapse dari hemoroid yang kemudian terpotong oleh spingter ani yang kemudian dapat menyebabkan trombosis (Black \& Jane, 2014).

Umumnya pada hemoroid grade III dan IV penatalaksaan dilakukan dengan terapi bedah yaitu hemoroidektomi, karena biasanya memberikan hasil yang baik. Prinsip eksisi dilakukan sehemat mungkin, pada jaringan yang berlebihan saja, dan tidak mengganggu sfingter ani. (Sjamsuhidajat, 2010). Saat ini hemoroidektomi masih dianggap sebagai gold strandard untuk penyembuhan hemoroid, karena berkinerja baik. Namun akibat dari prosedur bedah hemoroidektomi tersebut, eksisi setelah operasi akan menimbulkan rasa nyeri yang hebat (Shenoy \& Anitha, 2014). Seperti dalam jurnal yang menjelaskan bahwa nyeri klien post hemoroidektomi menjadi masalah besar, dan perlu mendapat pengelolaan yang lebih baik (Medina- Gallardo et al., 2017). Maka penatalaksanaan nyeri menjadi prioritas setelah operasi hemoroidektomi dilakukan. Akibat jika nyeri tidak segera ditangani maka dapat berpengaruh pada fisiologis, psikologis dan peilaku dari seseorang tersebut (Zakiyah, 2015). Bahkan klien pasca operasi hemoroidektomi bisa saja sampai pingsan karena nyeri (Black \& Jane, 2014). Pentingnya upaya penurunan nyeri dilakukan karena setelah pembedahan rektal akan menimbulkan nyeri pada sfingter dan perianal akibat terjadinya spasme. Sehingga nyeri menjadi pertimbangan utama (Smeltzer \& Bare, 2013). 
Teknik relaksasi nafas dalam dan teknik distraksi merupakan teknik nonfarmakologi untuk menurunkan nyeri (Wahyudi \& Abdul, 2016). Sesuai dengan penelitian yang menunjukkan bahwa teknik relaksasi nafas dalam dan teknik distraksi yang dapat menurunkan intensitas nyeri pada klien post operasi (Rampengan, Rondonuwu, \& Onibala, 2014).

Secara umum tujuan penulis adalah memberikan asuhan keperawatan pada klien dengan nyeri. Secara khusus tujuan penulis adalah memberikan 4 asuhan keperawatan pada klien dengan nyeri. Berdasarkan latar belakang diatas, upaya penurunan nyeri pada klien post hemoroidektomi menjadi priotitas perhatian. Maka penulis tertarik untuk menjelaskan dan menganalisis tentang penanganan kasus hemoroid dengan judul "Studi Kasus: Upaya Penurunan Nyeri Pada Klien Post Hemoroidektomi”".

\section{METODE PENELITIAN}

Metode yang digunakan dalam karya tulis ini adalah metode deskriptif dengan pemaparan studi kasus melalui pendekatan karya tulis yakni pengkajian, penegakan diagnosa keperawatan, perencanaan, implementasi, dan evaluasi keperawatan. Tempat pengambilan kasus dalam karya tulis ini. Waktu pelaksanaan studi kasus pada tanggal 5 - 7 Juli 2018. Penulisan karya tulis ini mengambil salah satu klien yaitu Ny.S dengan Hemoroid. Untuk mendapatkan data dalam penyusunan asuhan keperawatan ini melalui wawancara, pemeriksaan fisik dan observasi. Wawancara dilakukan dilakukan dengan mengajukan pertanyaan terbuka maupu tertutup yang dimaksudkan untuk mendapatkan data secara subyektif. Pemeriksaan fisik dilakukan dengan empat cara yaitu inspeksi, palpasi, perkusi, dan auskultasi. Sedangkan observasi dilakukan dengan mengamati respon fisik, psikologis, emosi, serta rasa aman dan nyaman dari klien (Debora, 2011). Serta untuk menyelesaikan karya tulis ini penulis juga mengumpulkan data dari berbagai sumber yaitu buku, jurnal, artikel dan web sebagai acuan.

\section{HASIL DAN PEMBAHASAN}

Pada hasil dan pembahasan memaparkan hasil dari kegiatan proses keperawatan yang dilakukan pada klien. Proses keperawatan dilakukan dengan tahapan dari pengkajian, diagnosa, perencanaan, implementasi kemudian evaluasi keperawatan (Potter \& Perry, 2009). 
Jurnal IImu Keperawatan Medial Bedah 1 (2), Desember 2018, 1-57

ISSN 2338-2058 (print), ISSN 2621-2986 (online)

Hasil Pengkajian Keperawatan

Hasil pengkajian yang dilakukan pada tanggal 5 Juli 2018 pukul 08.00 WIB didapatkan biodata klien yaitu nama $=\mathrm{Ny} . \mathrm{S}$, umur $=63$ tahun, jenis kelamin $=$ perempuan, agama $=$ Islam, suku $=$ Jawa, pendidikan $=\mathrm{SD}$, alamat $=$ Parakan. Biodata penanggungjawab yaitu nama $=\mathrm{Ny} . \mathrm{S}$, umur $=44$ tahun, jenis kelamin $=$ perempuan, agama $=$ Islam, alamat $=$ Parakan, pekerjaan $=$ wiraswasta, hubungan dengan klien $=$ anak. Catatan masuk klien yaitu klien masuk tanggal $=3$ Juli 2018, No. RM = 203xxx, bangsal = Gladiol, diagnosa medis = hemoroid interna grade III dengan anemia, tanggal pengkajian= 5 Juli 2018. Riwayat kesehatan klien didapatkan keluhan utama nyeri pada bagian anus. Klien mengatakan nyeri pada bagian anusnya. Pada pengkajian riwayat penyakit sekarang didapatkan klien mengatakan sudah merasakan nyeri dan didiagnosa hemoroid sejak 3 tahun yang lalu, sudah diperiksakan tapi hanya rawat jalan dari puskesmas dan rumah sakit lain. Pada tanggal 3 Juli 2018 karena klien BAB disertai banyak darah, hemoroid keluar dari anus, harus dimasukan kembali dengan jari tangan kemudian klien merasa lemas maka jam 22.45 WIB dibawa ke IGD RSK Ngesti Waluyo. Setelah menjalankan operasi hemoroidektomi, klien mengatakan sangat nyeri. Riwayat penyakit dahulu klien mengatakan sebelumnya pernah dirawat di rumah sakit sekitar 2 tahun lalu karena gula darah yang tinggi. Riwayat penyakit keluarga klien mengatakan keluarga tidak ada yang mempunyai penyakit menular maupun penyakit menurun seperti diabetes, hipertensi maupun asma, serta tidak ada yang mempunyai penyakit hemoroid. Dari keluarga klien, hanya klien yang mempunyai gula darah yang tinggi.

Pada pengkajian pola fungsi menurut Gordon didapatkan pada pola nutrisi sebelum sakit klien suka makan bubur, jarang makan buah, tidak melakukan diet, tidak ada pantangan makanan,makan porsi sedang tiga kali sehari dengan menu nasi, lauk dengan sedikit sayur, minum

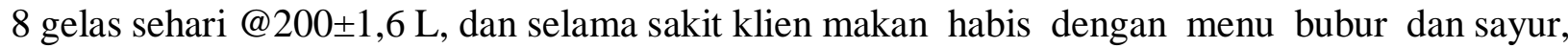
minum sehari $\pm 1,2$ L. Pada pola eliminasi didapatkan sebelum sakit klien BAB 1 kali dalam sehari, dengan konsistensi padat,sering mengejan saat BAB, kadang menahan BAB, BAK lancar 3-4 kali sehari@100 cc dikamar mandi secara mandiri, selama sakit klien belum BAB selama di rumah sakit, BAK 2-3 kali sehari @100 cc dikamar mandi dibantu keluarga. Pada pola aktivitas dan latihan sebelum sakit klien melakukan aktivitas secara mandiri, tidak beraktivitas terlalu banyak duduk, maupun mengangkat benda berat, selama sakit setelah operasi klien takut untuk bergerak, 
untuk melakukan kebutuhan sehari-hari dibantu oleh keluarga. Pada persepsi sensori dan kognitif klien sadar, orientasi baik, klien mengatakan nyeri setelah operasi, seperti disayat-sayat pisau, bagian anus, dengan skala 8 dan nyeri dirasakan terus menerus. Pemeriksaan fisik didapatkan hasil keadaan umum lemah, kesadaran composmentis, tekanan darah : 130/70 mmHg, pernafasan: $22 \mathrm{kali} /$ menit, nadi : $80 \mathrm{kali} / \mathrm{menit}$, suhu : $36,7^{\circ} \mathrm{C}, \mathrm{BB}: 54 \mathrm{~kg}$, TB : $155 \mathrm{~cm}$. Hasil pemeriksaan fisik didapatkan anus berwarna hitam, anus terpasang tampon kassa, perdarahan yang terjadi tidak banyak karena tidak sampai merembes dari tampon kassa. Pada pemeriksaan penunjang hasil hematologi pada tanggal 5 Juli 2018 didapatkan Hemoglobin 9,5 g/dl (12,0-16,0), lekosit 10,1 $10^{\wedge} 3 / \mathrm{uL}(4,0-12,0)$, trombosit $310,010^{\wedge} 3 / \mathrm{uL} \quad(150,0-400,0), \quad$ eritrosit $3,8710^{\wedge} 6 / \mathrm{uL}(4,00-$ $5,00)$, hematokrit 30,2 vol\% (37,0-43,0), granulosit 71,7 \% (50,0-80,0), limfosit 19,2\% (20,551,1), monosit $9 \%$ (2-9), MCV 78,0 u^3 (78,6-102,2), MCH 24,5 pg (25,2-34,7), MCHC 31,5 $\mathrm{g} / \mathrm{dl}(31,3-35,4)$.

Dari pengkajian diatas diperoleh data subyektif dan obyektif. Data subyektif klien mengatakan nyeri setelah operasi, seperti disayat-sayat pisau, bagian anus, dengan skala 8 dan nyeri dirasakan terus menerus. Data obyektif : klien tampak menahan nyeri dengan ekspresi wajah meringis kesakitantekanan darah : 130/70 $\mathrm{mmHg}$, pernafasan : $22 \mathrm{kali} /$ menit, nadi : $80 \mathrm{kali} / \mathrm{menit}$, suhu : 36,7o C, BB : $54 \mathrm{~kg}$, TB : $155 \mathrm{~cm}$. Terapi tanggal 5 Juli 2018 klien mendapatkan terapi infus RL + Tramadol $20 \mathrm{tpm}$, asam traneksamat $500 \mathrm{mg} / 8 \mathrm{jam}$, ranitidine $50 \mathrm{mg} / 12 \mathrm{jam}$, ferzobat 1gr/12jam, ketorolac $30 \mathrm{mg} / 8 \mathrm{jam}$.

\section{Diagnosa Keperawatan}

Setelah didapatkan data dari pengkajian yang dilakukan secara menyeluruh, maka dibuatlah analisa data dan membuat kesimpulan diagnosis keperawatan (Potter \& Perry, 2009). Berikut adalah analisa data dari hasil pengkajian kepada klien dengan data subyektif klien mengatakan nyeri setelah operasi, seperti disayat-sayat pisau, bagian anus, dengan skala 8 dan nyeri dirasakan terus menerus. Data obyektif klien tampak menahan nyeri dengan ekspresi wajah meringis kesakitan. tekanan darah : 130/70 $\mathrm{mmHg}$, pernafasan : $22 \mathrm{kali} /$ menit, nadi : $82 \mathrm{kali} / \mathrm{menit}$, suhu : $36^{\circ} \mathrm{C}$. Berdasarkan data diatas maka ditegakkan diagnosa keperawatan yaitu nyeri akut berhubungan dengan agen cedera fisik (prosedur bedah) (NANDA, 2015). 
Jurnal IImu Keperawatan Medial Bedah 1 (2), Desember 2018, 1-57

ISSN 2338-2058 (print), ISSN 2621-2986 (online)

Intervensi Keperawatan

Intervensi yang dibuat untuk diagnosa diatas adalah tujuan yang diharapkan dari tindakan keperawatan 3x24 jam yang dilakukan yaitu nyeri berkurang. Dengan kriteria hasil klien mampu mengontrol dengan menggunakan teknik non farmakologi, melaporkan nyeri berkurang dengan manajemen nyeri, klien mampu mengenali nyeri (penyebab, skala, intensitas, frekuensi dan tanda nyeri), menyatakan rasa nyaman setelah nyeri berkurang(Nurarif \& Hardhi, 2015).

Rencana tindakan keperawatan yang akan dilakukan adalah monitor tanda- tanda vital (Nurarif \& Hardhi, 2015), lakukan pengkajian nyeri secara komprehensif meliputi lokasi, karakteristik, durasi, frekuensi, kualitas dan faktor presipitasi. Ajarkan manajemen nyeri menggunakan teknik nonfarmakologi, ajarkan teknik relaksasi nafas dalam ketika nyeri muncul, ajarkan teknik distraksi bila nyeri muncul, lakukan stimulasi kutaneus atau sentuhan (Bulechek, et al, 2013). Anjurkan klien untuk memilih posisi yang nyaman,dan berikan bantalan saat duduk (Smeltzer \& Bare, 2013). Berikan informasi mengenai nyeri, kolaborasi dengan dokter pemberian analgetik untuk menurunkan nyeri (Bulechek et al., 2013).

Berdasarkan perencanaan yang dibuat, hanya tiga tindakan keperawatan mandiri yang dilakukan yaitu menganjurkan klien untuk memilih posisi yang nyaman dan memberikan bantalan saat duduk, mengajarkan klien relaksasi nafas dalam, dan mengajarkan klien teknik distraksi. Tindakan menganjurkan klien memilih posisi yang nyaman dan memberikan bantalan saat duduk,mengajarkan teknik relaksasi nafas dalam, dan teknik distraksi dirasa cukup efektif untuk menurunkan nyeri.

\section{$\underline{\text { Implementasi Keperawatan }}$}

Penulis akan memaparkan implementasi mulai tanggal $5-7$ Juli 2018. Tindakan keperawatan tanggal 5 Juli 2018 jam 08.00 WIB mengkaji nyeri secara komprehensif. Data subyektif : klien mengatakan nyeri setelah operasi, seperti disayat-sayat pisau, bagian anus, dengan skala 8 dan nyeri dirasakan terus menerus. Klien mengatakan setelah operasi tidak berani berganti posisi karena sakit, hanya berbaring saja. Data obyektif: klien tampak menahan nyeri dengan ekspresi wajah meringis kesakitan. Jam 08.30 WIB mengajarkan teknik relaksasi nafas dalam. Data subyektif: klien mengatakan lebih enakan, tapi masih nyeri, skala 7. Data obyektif: Ediyanto, A.K. / Studi Kasus: Upaya Penurunan Nyeri Pada Klien Post Hemoroidektomi...Hal $\mathbf{3 7}$ dari $\mathbf{5 7}$ 
Jurnal IImu Keperawatan Medial Bedah 1 (2), Desember 2018, 1-57

ISSN 2338-2058 (print), ISSN 2621-2986 (online)

klien tampak lebih rileks, klien sudah bisa melakukan nafas dalam dengan baik. Jam 10.30 WIB mengukur TANDA VITAL. Data subyektif: klien mengatakan bersedia dilakukan tindakan. Data obyektif: tekanan darah: 130/70 mmHg, frekuensi nadi: $82 \mathrm{kali} / \mathrm{menit}$, frekuensi pernapasan: 22 kali/menit, suhu: $36^{\circ} \mathrm{C}$. Jam 10.45 WIB menganjurkan klien memilih posisi yang nyaman. Data subyektif: klien mengatakan lebih nyaman berbaring. Data obyektif: klien tampak lebih rileks. Jam 11.15 WIB kolaborasi dengan dokter untuk pemberian obat asam traneksamat $500 \mathrm{mg}$, ranitidine $50 \mathrm{mg}$, ferzobat $1 \mathrm{gr}$, ketorolac $30 \mathrm{mg}$. Data subyektif: klien mengatakan sedikit sakit saat disuntik. Data obyektif: klien tampak menahan nyeri saat obat diinjeksikan, obat masuk diinjeksikan melalui intravena.

Tindakan keperawatan tanggal 6 Juli 2018 jam 08.00 WIB mengobservasi tingkat nyeri. Dat a subyektif: klien mengatakan nyeri pada luka operasi, nyeri seperti tersayat-sayat pisau, bagian anus, skala nyeri 6, terus menerus. Data obyektif: ekspresi wajah klien tampak menahan nyeri. Jam 08.15 WIB menganjurkan posisi yang nyaman. Data subyektif: klien mengatakan lebih nyaman miring, kadang duduk sebentar. Data obyektif: klien tampak tenang, klien bisa miring dan duduk walaupun sebentar. Jam 08.30 WIB menganjurkan memberikan bantalan saat duduk. Data subyektif: klien mengatakan lebih enakan saat diberi bantalan saat duduk, skala nyeri 6. Data obyektif: klien tampak lebih rileks saat duduk. Jam 09.00 WIB menganjurkan klien nafas dalam dan mengajarkan teknik distraksi. Data subyektif: klien mengatakan lebih enakan, skala nyeri 5. Data obyektif: klien tampak rileks dan menikmati musik islami yang didengarkan. Jam 10.30 WIB mengukur tanda vital. Data subyektif: klien mengatakan bersedia dilakukan tindakan. Data obyektif: tekanan darah : 110/60 mmHg, nadi : $84 \mathrm{kali} / \mathrm{menit}$, pernafasan : 20 kali/menit, suhu : 36,4 oC. Jam 11.00 WIB kolaborasi dengan dokter untuk pemberian obat asam traneksamat $500 \mathrm{mg}$, ranitidine $50 \mathrm{mg}$, ferzobat $1 \mathrm{gr}$, ketorolac $30 \mathrm{mg}$. Data subyektif: klien mengatakan nyeri saat disuntik. Data obyektif: klien tampak menahan nyeri dengan ekspresi wajah meringis.

Tindakan keperawatan tanggal 7 Juli 2018 jam 08.00 WIB mengobservasi tingkat nyeri. Data subyektif: klien mengatakan nyeri pada luka operasi, nyeri seperti tersayat-sayat pisau, bagian anus, skala nyeri 4, terus menerus. Data obyektif: ekspresi wajah klien tampak menahan nyeri. Jam 09.00 WIB mengobservasi penggunaan relaksasi nafas dalam dan teknik distraksi. Data subyektif: klien mengatakan saat nyeri melakukan nafasdalam, kadang juga mendengarkan musik Ediyanto, A.K. / Studi Kasus: Upaya Penurunan Nyeri Pada Klien Post Hemoroidektomi... Hal 38 dari 57 
Jurnal IImu Keperawatan Medial Bedah 1 (2), Desember 2018, 1-57

ISSN 2338-2058 (print), ISSN 2621-2986 (online)

islami. Data obyektif: klien tampak lebih rilek. Jam 10.30 WIB mengukur TANDA VITAL. Data subyektif: klien mengatakan bersedia dilakukan tindakan. Data obyektif: tekanan darah : 110/70 mmHg, nadi : $80 \mathrm{kali} / \mathrm{menit}$, pernafasan : $20 \mathrm{kali} / \mathrm{menit}$, suhu : 36,2 ${ }^{0} \mathrm{C}$. Jam 11.30 WIB kolaborasi dengan dokter untuk pemberian obat asam traneksamat $500 \mathrm{mg}$, ranitidine $50 \mathrm{mg}$, ferzobat 1gr, ketorolac $30 \mathrm{mg}$. Data subyektif: klien mengatakan nyeri saat disuntik. Data obyektif: klien tampak menahan nyeri dengan ekspresi wajah meringis.

\section{Evaluasi Keperawatan}

Setelah melakukan implementasi sesuai dengan perencanaan, maka perawat membandingkan hasil tindakan dengan kriteria hasil yang sudah ditetapkan (Debora, 2011). Evaluasi harus dilakukan secara periodic tidak hanya satu kali saja untuk menentukan adanya perubahan atau perbaikan kondisi klien (Potter \& Perry, 2009). Evaluasi pada tanggal 5 Juli 2018 jam 14.00 WIB Subyektif : klien mengatakan sudah lebih enakan, nyeri setelah operasi, seperti disayat-sayat pisau, bagian anus, skala nyeri berkurang sedikit skala 7 dan nyeri dirasakan terus menerus. Obyektif : klien tampak menahan nyeri dengan ekspresi wajah meringis kesakitan, tekanan darah : 130/70 mmHg, frekuensi nadi : $82 \mathrm{kali} /$ menit, frekuensi pernafasan : $22 \mathrm{kali} / \mathrm{menit}$, suhu : $36^{\circ} \mathrm{C}$. Assesment : Masalah teratasi sebagian. Planning : Intervensi dilanjutkan; kaji nyeri secara komprehensif, anjurkan klien memilih posisi yang nyaman dan berikan bantalan saat duduk, anjurkan penggunaan teknik relaksasi nafas dalam saat nyeri muncul, ajarkan teknik distraksi, berikan informasi mengenai nyeri, serta kolaborasi dengan dokter untuk pemberian analgesik.

Evaluasi pada tanggal 6 Juli 2018 jam 14.00 WIB. Subyektif : klien mengatakan nyeri setelah operasi, seperti tersayat pisau, bagian anus, dengan skala 5, terus menerus. Obyektif : klien tampak lebih nyaman, rileks dengan tekanan darah: 110/60 mmHg, frekuensi nadi : 84 kali/menit, frekuensi pernafasan : $20 \mathrm{kali} / \mathrm{menit}$, suhu : $36,4^{\circ} \mathrm{C}$. Assesment: masalah teratasi sebagian. Planning: Intervensi dilanjutkan; kaji nyeri secara komprehensif, observasi penggunaan teknik relaksasi nafas dalam, anjurkan penggunaan teknik distraksi saat nyeri muncul, berikan informasi mengenai nyeri, kolaborasi dengan dokter untuk pemberian analgesik.

Evaluasi pada tanggal 7 Juli 2018 jam 14.00 WIB. Subyektif : klien mengatakan nyeri setelah operasi, seperti tersayat pisau, bagian anus, skala 4, terus menerus. Obyektif : klien tampak lebih nyaman, tekanan darah : 110/70 $\mathrm{mmHg}$, frekuensi nadi : $80 \mathrm{kali} / \mathrm{menit}$, frekuensi pernafasan Ediyanto, A.K. / Studi Kasus: Upaya Penurunan Nyeri Pada Klien Post Hemoroidektomi... Hal 39 dari 57 
Jurnal IImu Keperawatan Medial Bedah 1 (2), Desember 2018, 1-57

ISSN 2338-2058 (print), ISSN 2621-2986 (online)

: $20 \mathrm{kali} / \mathrm{menit}$, suhu : $36,2{ }^{\circ} \mathrm{C}$. Assesment : masalah teratasi sebagian. Planning : intervensi dilanjutkan; ; kaji nyeri secara komprehensif, observasi penggunaan teknik relaksasi nafas dalam dan teknik distraksi, berikan informasi mengenai nyeri, kolaborasi dengan dokter untuk pemberian analgesik.

\section{Pembahasan}

Pengkajian Keperawatan. Pengkajian merupakan langkah pertama dalam proses keperawatan. Pengkajian dilakukan bertujuan untuk mendapatkan data dasar yang digunakan untuk menetapkan status kesehatan klien, menentukan masalah actual atau potensial (Debora, 2011). Sesuai data keluhan utama klien adalah nyeri pada bagian anus. Pada keadaan klien riwayat kesehatan sekarang didapatkan klien sudah merasakan nyeri dan di diagnosa hemoroid sejak 3 tahun yang lalu, kemudian klien BAB disertai banyak darah, hemoroid keluar dari anus, harus dimasukan kembali dengan jari tangan kemudian klien merasa lemas. Dalam pengkajian didapatkan kesesuaian dengan teori dimana nyeri dapat dialami klien pasca hemoroidektomi (Shenoy \& Anitha, 2014) akibat spasme yang menimbulkan nyeri pada sfingter dan otot perianal serta perlu menjadi pertimbangan utama (Smeltzer \& Bare, 2013). Pada tanda dan gejala yang dialami oleh Ny.S sesuai dengan teori bahwa hemoroid biasanya menyebabkan nyeri dan perdarahan berwarna merah segar saat defekasi (Smeltzer \& Bare, 2013) dan hemoroid yang kian membesar akan menonjol keluar dan menyebabkan prolaps (Sjamsuhidajat, 2010). Pada klien dengan keluhan prolaps keluar sebagian setelah defekasi, jika hemoroid masuk kembali (grade II) jika harus dimasukkan dengan bantuan jari tangan (grade III) (Shenoy \& Anitha, 2014).

Hasil pemeriksaan penunjang hematologidengan hasil Hemoglobin 9,5 g/dl, eritrosit 3,87 10^6/uL menunjukkan bahwa klien mengalami anemia. Sesuai teori bahwa bahwa dari perdarahan merah segar yang terjadi saat defekasi akan menyebabkan anemia kronis (Shenoy \& Anitha, 2014) dan bahkan kadar hemoglobin bisa mencapai $4 \mathrm{~g} / \mathrm{dl}$. Namun harus dicari penyebab perdarahan dari yang lain (Rani, Simadibrata, \& Syam, 2011). Perdarahan umumnya tanda awal dari hemoroid interna akibat feses yang keras (Sjamsuhidayat, 2010).

Pada pengkajian pola fungsi menurut Gordon didapatkan pada pola nutrisi sebelum sakit klien suka makan bubur, jarang makan buah, tidak melakukan diet, tidak ada pantangan makanan, makan porsi sedang tiga kali sehari dengan menu nasi, lauk dengan sedikit sayur, dan 
selama sakit klien makan habis dengan menu bubur dan sayur. Pada pola eliminasi didapatkan sebelum sakit klien $\mathrm{BAB}$ sering mengejan saat $\mathrm{BAB}$, kadang menahan $\mathrm{BAB}$, selama sakit klien belum BAB selama di rumah sakit. Pada pola aktivitas dan latihan sebelum sakit klien tidak beraktivitas terlalu banyak duduk, maupun mengangkat benda berat, selama sakit setelah operasi klien takut untuk bergerak, untuk melakukan kebutuhan sehari-hari dibantu oleh keluarga. Klien yang jarang makanan tinggi serat, sering mengejan saat $\mathrm{BAB}$, kadang menahan $\mathrm{BAB}$, akan beresiko menjadi konstipasi kemudian meningkatkan tekanan vena hemoroidalis dimana pada keadaan tersebut dapat meningkatkan resiko terjadinya hemoroid (Black \& Jane, 2014). Serta faktor resiko paling tinggi dari hemoroid adalah aktivitas fisik sering mengejan saat BAB (Sunarto, 2016). Sebagai akibat obstruksi atau peningkatan tekanan yang berulang akan menyebabkan dilatasi vena hemoroidalis menjadi permanen dan akan semakin parah dapat terjadi thrombosis dan perdarahan (Black \& Jane, 2014).

Pada persepsi sensori dan kognitif klien sadar, orientasi baik, klien mengatakan nyeri setelah operasi, seperti disayat-sayat pisau, bagian anus, dengan skala 8 dan nyeri dirasakan terus menerus. Pemeriksaan fisik didapatkan hasil keadaan umum lemah, kesadaran compos mentis, Tanda Vital : tekanan darah : 130/80 mmHg, frekuensi pernafasan : $22 \mathrm{kali} /$ menit, frekuensi nadi

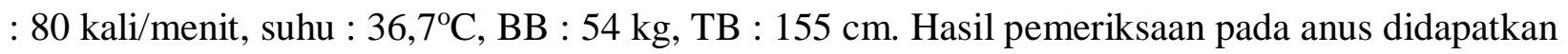
anus berwarna hitam, anus terpasang tampon kassa. Karena nyeri yang bersifat subyektif dan unik pada setiap individu, maka pengkajian nyeri yang komprehensif sangat diperlukan sebagai acuan dalam memberikan manajemen nyeri yang tepat (Zakiyah, 2015). Pengkajian komprehensif pada nyeri mencakup pada lima hal yaitu Provoking atau pemicu nyeri, Quality atau kualitas nyeri, Region atau lokasi nyeri, Severity atau skala nyeri, dan Time atau waktu serangan dan frekuensi nyeri (Saputra, 2013).

Diagnosa Keperawatan. Diagnosa keperawatan adalah suatu penilaian klinis terhadap gangguan kesehatan atau proses kehidupan tentang respon dari individu, keluarga, kelompok atau komunitas. (NANDA, 2015). Hasil analisa data didapatkan data subyektif klien mengatakan nyeri setelah operasi, seperti disayat-sayat pisau, bagian anus, dengan skala 8 dan nyeri dirasakan terus menerus. Klien mengatakan setelah operasi tidak berani berganti posisi karena sakit, hanya berbaring saja. Data obyektif klien tampak menahan nyeri dengan ekspresi wajah meringis kesakitan. tekanan darah : 130/80 mmHg, frekuensi pernafasan : $22 \mathrm{kali} /$ menit, frekuensi nadi : Ediyanto, A.K. / Studi Kasus: Upaya Penurunan Nyeri Pada Klien Post Hemoroidektomi... Hal 41 dari 57 
Jurnal IImu Keperawatan Medial Bedah 1 (2), Desember 2018, 1-57

ISSN 2338-2058 (print), ISSN 2621-2986 (online)

$80 \mathrm{kali} / \mathrm{menit}$, suhu : $36,7^{\circ} \mathrm{C}$. Maka ditegakkan diagnosa keperawatan yaitu nyeri akut berhubungan dengan agen cedera fisik (prosedur bedah) (NANDA, 2015). Sesuai dengan teori bahwa pada klien post hemoroidektomi akan muncul diagnosa nyeri sebagai prioritas dan pertimbangan utama (Smeltzer \& Bare, 2013).

Nyeri akut merupakan pengalaman sensoris atau emosional yang terjadi setelah cedera akut, akibat dari suatu intervensi bedah atau penyakit yang berlangsung singkat atau kurang dari enam bulan dengan intensitas nyeri dari ringan sampai berat (Wahyudi \& Abdul, 2016). Pada masalah keperawatan nyeri akut, dapat dipengaruhi beberapa faktor yaitu agen cedera biologis seperti infeksi, agen cedera fisik seperti luka bakar, prosedur bedah, dan agen cedera kimiawi misalnya luka bakar.(NANDA, 2015).

Intervensi Keperawatan. Setelah menentukan diagnosa keperawatan maka tahap selanjutnya adalah membuat perencanaan keperawatan yang merupakan tindakan merumuskan perawatan yang diarahkan untuk mengatasi atau mengurangi keparahan masalah yang muncul dan risiko terjadinya masalah (NANDA, 2015). Rencana tindakan keperawatan yang akan dilakukan adalah monitor tanda- tanda vital (Nurarif \& Hardhi ,2015), lakukan pengkajian nyeri secara komprehensif meliputi lokasi, karakteristik, durasi, frekuensi, kualitas dan faktor presipitasi. Ajarkan manajemen nyeri menggunakan teknik nonfarmakologi, ajarkan teknik relaksasi nafas dalam ketika nyeri muncul, ajarkan teknik distraksi bila nyeri muncul, lakukan stimulasi kutaneus atau sentuhan (Bulechek et al., 2013). Anjurkan klien untuk memilih posisi yang nyaman,dan berikan bantalan saat duduk (Smeltzer \& Bare, 2013). Berikan informasi mengenai nyeri, kolaborasi dengan dokter pemberian analgetik untuk menurunkan nyeri (Bulechek et al., 2013). Dalam hal ini, peneliti berfokus pada tindakan manajemen nyeri menggunakan teknik nonfarmakologi yaitu ajarkan teknik relaksasi nafas dalam ketika nyeri muncul rasional relaksasi dapat merilekskan otot yang menimbulkan nyeri, ajarkan teknik distraksi bila nyeri muncul, rasional distraksi akan menstimulasi sistem kontrol desenden sehingga mengurangi stimulasi nyeri ke otak (Wahyudi \& Abdul, 2016).Anjurkan klien untuk memilih posisi yang nyaman, dan berikan bantalan saat duduk rasionalnya kenyamanan akan merilekskan dan dapat menurunkan nyeri (Smeltzer \& Bare, 2013). 
Jurnal IImu Keperawatan Medial Bedah 1 (2), Desember 2018, 1-57

ISSN 2338-2058 (print), ISSN 2621-2986 (online)

Alasan peneliti hanya melakukan tiga tindakan keperawatan adalah untuk kenyamanan klien karena menurut penulis apabila terlalu banyak tindakan keperawatan yang dilakukan dikhawatirkan kenyamanan klien akan terganggu. Tindakan menganjurkan klien memilih posisi yang nyaman dan memberikan bantalan saat duduk, mengajarkan teknik relaksasi nafas dalam, dan teknik distraksi dirasa cukup efektif untuk menurunkan nyeri.Tindakan menganjurkan klien memilih posisi yang nyaman dan memberikan bantalan saat duduk, dirasa cukup efektif untuk menurunkan nyeri (Smeltzer \& Bare, 2013). Kemudian, berdasarkan penelitian bahwa teknik relaksasi nafas dalam secara signifikan dapat menurunkan nyeri pada klien (Agung, Andriyani, \& Sari, 2013) teknik relaksasi dan teknik distraksi mampu menurunkan intensitas nyeri pada klien post operasi (Rampengan, Rondowunu, \& Onibala, 2014).

Implementasi Keperawatan. Implementasi merupakan tahap yang muncul setelah perencanaan dibuat yang diaplikasikan pada klien. Tindakan yang dilakukan mungkin akan sama namun aplikasi yang dilakukan pada klien akan berbeda disesuaikan dengan kebutuhan yang paling dirasakan oleh klien dan kondisiklien saat itu (Debora, 2011). Berdasarkan tindakan keperawatan yang dilakukan penulis selama 3x24 bertujuan untuk menurunkan nyeri, tindakan keperawatan yang dilakukan adalah menganjurkan klien memilih posisi yang nyaman, memberikan bantalan saat duduk untuk memberikan kenyamanan pada klien, mengajarkan teknik relaksasi nafas dalam dan teknik distraksi dapat merileksasikan otot, dan memblok transmisi impuls nyeri dan memberikan injeksi analgesik yaitu ketorolac $30 \mathrm{mg}$ yang berfungsi menurunkan nyeri akutderajat sedang hingga berat segera setelah operasi yang diindikasikan untuk penatalaksanaan jangka pendek maksimal 2 hari, dan tramadol $100 \mathrm{mg}$ yang diberikan melalui infus RL dengan faktor tetesan 20 tpm yang berfungsi sebagai pengobatan untuk nyeri akut dan kronik berat, nyeri pasca operasi (ISFI, 2009).

Selain teknik relaksasi nafas dalam, teknik distraksi dan stimulus sentuhan yang disebutkan penulis dalam perencanaan, sebenarnya ada banyak tindakan nonfarmakologi yang dapat menurunkan nyeri seperti stimulasi, listrik syaraf transkutaneus (TENS), hypnosis, terapi musik, akupresur, kompres panas atau dingin dan pijatan (Bulechek et al., 2013). Tetapi tindakan tersebut jarang dilakukan karena banyaknya klien dan anggota tim kesehatan lebih cenderung berfokus kepada obat sebagai satu-satunya metode untuk menurunkan nyeri. Meskipun metode pereda nyeri tersebut bukan merupakan pengganti obat-obatan tetapi tindakan tersebut mungkin 
Jurnal Ilmu Keperawatan Medial Bedah 1 (2), Desember 2018, 1-57

ISSN 2338-2058 (print), ISSN 2621-2986 (online)

diperlukan. Namun dalam implementasi diatas penulis berfokus pada tindakan nonfarmakologi teknik relaksasi nafas dalam, teknik distraksi, dan menganjurkan memilih posisi yang nyaman.

Evaluasi Keperawatan. Evaluasi adalah tahap dimana membandingkan hasil tindakan yang dilakukan dengan kriteria hasil yang sudah ditetapkan dalam perencanaan serta menilai apakah masalah sudah teratasi seluruhnya,hanya sebagian atau belum teratasi (Debora, 2011).

Berdasarkan tindakan keperawatan 3x24 jam yang telah dilakukan oleh penulis, dilakukan evaluasi keperawatan dengan diagnosa nyeri akut berhubungan dengan agen cedera fisik dengan hasil masalah teratasi sebagian, sehingga intervensi dilanjutkan : informasikan kepada klien saat nyeri muncul, anjurkan untuk menggunakan teknik manajemen nyeri nonfarmakologi, kolaborasi dengan dokter untuk pemberian analgesik.

Evaluasi yang dilakukan selama tiga hari dengan hasil terjadi penurunan skalanyeri dari hari pertama skala nyeri 8 menjadi 4. Dari hasil evaluasi diatas maka dapat disimpulkan tindakan nonfarmakologi yang diajarkan penulis efektif dalam menurunkan nyeri, seperti yang sudah dibuktikan pada jurnal (Rampengan, Rondonuwu, Onibala, 2014) yang menunjukkan bahwa teknik relaksasi nafas dalam dan teknik distraksi dapat menurunkan nyeri pada klien post operasi.

\section{KESIMPULAN}

Kesimpulan yang didapat pada studi kasus ini antara lain:

1. Hasil pengkajian didapatkan diagnosa keperawatan pada Ny.S yaitu nyeri akut berhubungan dengan agen cedera fisik (prosedur bedah).

2. Intervensi keperawatan pada klien dengan diagnosa keperawatan nyeri akut berhubungan dengan agen cedera fisik (prosedur bedah) antara lain : lakukan pengkajian nyeri secara komprehensif meliputi lokasi, karakteristik, durasi,frekuensi, kualitas dan faktor presipitasi, ajarkan manajemen nyeri menggunakan teknik non-farmakologi yaitu anjurkan klien untuk memilih posisi yang nyaman, dan berikan antalan saat duduk, ajarkan teknik relaksasi nafas dalam ketika nyeri muncul, ajarkan teknik distraksi bila nyeri muncul, lakukan stimulus kutaneus atau sentuhan, berikan informasi tentang nyeri, kolaborasi dengan dokter pemberian analgetik untuk menurunkan nyeri.

3. Implementasi yang dilakukan adalah mengajarkan teknik nonfarmakologi yaitu menganjurkan klien memilih posisi yang nyaman dan memberikan bantalan saat duduk, mengajarkan teknik Ediyanto, A.K. / Studi Kasus: Upaya Penurunan Nyeri Pada Klien Post Hemoroidektomi... Hal 44 dari 57 
relaksasi nafas dalam, mengajarkan teknik distraksi, dan berkolaborasi dengan dokter untuk pemberian analgesik yaitu asam traneksamat $500 \mathrm{mg}$, ranitidine $50 \mathrm{mg}$, ferzobat $1 \mathrm{gr}$, ketorolac $30 \mathrm{mg}$. Sedangkan implementasi yang tidak dilakukan adalah melakukan stimulus kutaneus atau sentuhan, dan memberikan informasi tentang nyeri, karena menurut penulis apabila terlalu banyak tindakan keperawatan yang dilakukan dikhawatirkan kenyamanan klien akan terganggu.

4. Evaluasi dari diagnosa keperawatan nyeri akut berhubungan dengan agen cedera fisik (prosedur bedah) masalah teratasi sebagian. Intervensi dilanjutkan : informasikan kepada klien saat nyeri muncul, anjurkan untuk menggunakan teknik manajemen nyeri nonfarmakologi, kolaborasi dengan dokter untuk pemberian analgesik.

5. Pemberian teknik nonfarmakologi yaitu menganjurkan memilih posisi nyaman dan memberikan bantalan saat duduk, mengajarkan teknik relaksasi nafas dalam, teknik distraksi pada Ny.S dengan diagnosa nyeri akut berhubungan dengan agen cedera fisik (prosedur bedah) dalam menurunkan nyeri terbukti efektif dari skala nyeri 8 menjadi 4.

\section{DAFTAR PUSTAKA}

Agung, S., Andriyani, A., \& Sari, D.K. (2013). Pengaruh pemberian teknik relaksasi nafas dalam terhadap tingkat nyeri pada pasien post operasi dengan anestesi umum di RSUD Dr. Moewardi Surakarta. Jurnal Ilmiah Rekam Medis dan Informatika Kesehatan, 3(1), 52-60.

Black, J.M. \& Jane, H.H. (2014). Keperawatan medikal bedah manajemen klinis untuk hasil yang diharapkan. Edisi 8: Elseiver.

Bulechek, G.M., Butcher, H.K., Dochterman, J.M., \&Wagner, C.M. (2013). Nursing Interventions Classification (NIC). Edisi Keenam: Elseiver.

Debora, O. (2011). Proses Keperawatan dan Pemeriksaan Fisik. Jakarta: Salemba Medika.

ISFI. (2009). ISO Informasi Spesialite Obat Indonesia. Volume 44. Jakarta: PT.ISFI Penerbitan.

Medina-Gallardo, A., Curbelo-Pena, Y., Castro, X. De, Roura-poch, P., Roca-Closa, J., \& CaraltMestres, E. De. (2017). Case Report - Open Access International Journal of Surgery Case Reports. Is the severe pain after Milligan-Morgan hemorrhoidectomy still currently remaining a major postoperative problem despite being one of the oldest surgical techniques described ? A cas. International Journal of Surgery Case Reports, 30, 73-75. https://doi.org/10.1016/j.ijscr.2016.11.018. 
Jurnal IImu Keperawatan Medial Bedah 1 (2), Desember 2018, 1-57

ISSN 2338-2058 (print), ISSN 2621-2986 (online)

NANDA. (2015). Diagnosis keperawatan: definisi \& klasifikasi 2015-2017. Edisi 10. Jakarta: EGC.

Nurarif, A.H., \& Hardhi, K. (2015). Aplikasi asuhan keperawatan berdasarkan diagnosa medis \& Nanda NIC-NOC. Yogyakarta: MediAction.

Potter, P.A., \& Perry, A.G. (2009). Fundamental of nursing : fundamental keperawatan. Buku 1. Edisi 7. Jakarta: Salemba Medika.

Rampengan, S.F., Rondonuwu, R., \& Onibala, F. (2014). Pengaruh teknik relaksasi dan teknik distraksi terhadap perubahan intensitas nyeri pada klien post operasi di ruang Irina A atas RSUP Prof. Dr. Rd Kandou Manado. Jurnal Keperawatan, 2(2).

Riss, S., Weiser, F.A., Schwameis, K., Riss, T., Mittlbock, M., Steiner, G., \& Stift, A. (2012). The prevalence of hemorrhoids in adults. International Journal of Colorectal Disease. 27(2), $215-220$.

Septadina, I.S., \& Veronica, F. (2015). Gambaran histopatologi epitel transisional kolorektal pada pasien hemoroid. Jurnal Kedokteran dan Kesehatan, 2(1), 85-91.

Sunarto. (2016). Analisis faktor aktifitas fisik resiko terjadi hemoroid di klinik etika. Jurnal Keperawatan Global, 2(1), 94-99.

Shenoy, R \& Anitha, N. (2014). Buku ajar ilmu bedah ilustrasi berwarna. Jilid Dua. Edisi Ketiga.

Sjamsuhidayat. (2010). Buku ajar ilmu bedah. Jakarta: EGC.

Smeltzer, S.C., \& Bare, B.G. (2013). Buku ajar keperawatan medikal-bedah Brunner \& Suddarth. Edisi 8. Vol. 2. Jakarta: EGC.

Wahyudi, A.S., \& Abdul, W. (2016). Buku ajar ilmu keperawatan dasar. Jakarta: Mitra Wacana Media.

Zakiyah, A. (2015). Nyeri konsep dan penatalaksanaan dalam praktik keperawatan berbasis bukti. Jakarta: Salemba Medika.

Ediyanto, A.K. / Studi Kasus: Upaya Penurunan Nyeri Pada Klien Post Hemoroidektomi...Hal 46 dari 57 